\author{
${ }^{1}$ University of Göttingen, Göttingen, Germany \\ ${ }^{2}$ Research Institute for the Biology of Farm Animals (FBN), Dummerstorf, Germany \\ DANIEL MÖRLEIN ${ }^{1}$, GREGOR LINK ${ }^{1}$, EDUARD MURANI ${ }^{2}$, KLAUS WIMMERS $^{2}$ and \\ MICHAEL WICKE ${ }^{1}$
}

\title{
Evaluation of three pig crossbreed types with respect to strategies to improve the meat quality: MHS genotype rather than crossbreed type influences drip loss
}

\begin{abstract}
While focussing on drip loss, the aim of this investigation was to evaluate routine parameters of technological meat quality, conductivity, $\mathrm{pH}$ for prediction of drip loss and means to discriminate superior carcasses suitable for premium meat programs at slaughter. Thus, 534 carcasses of three commercially available crossbred pigs were examined and effects of crossbreed type and stress susceptibility type (MHS genotype NN or NP) on carcass traits and meat quality characteristics were evaluated. The animals were produced and slaughtered under commercial conditions. Finally we simulated a meat quality program based on electrical conductivity measurements that aimed at exclusion of inferior carcasses in terms of drip loss.

NN carcasses yielded $2 \%$ less drip loss compared to NP carcasses. Comparing the crossbreds, breed S pigs appeared most favourable because of lowest drip. Most probably that is due to the $25 \%$ Duroc proportion of that crossbred compared to $0 \%$ Duroc in the competitive crossbreds. Of all quality indicators obtained, conductivity measured 24 h p.m. (EC24) was closest related to drip loss. Above all breeds, a remarkable decrease of drip can be achieved by application of EC24 measurements and corresponding sorting of the carcasses. Therefore, to establish a meat quality program, careful consideration of crossbred, MHS genotype and discrimination of superior carcasses at slaughter based on EC24 measurements is recommended.
\end{abstract}

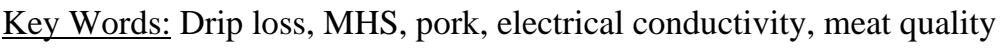

\section{Zusammenfassung}

Titel der Arbeit: Vergleich von 3 Kreuzungsherkünften im Hinblick auf ihre Eignung für ein Qualitätsfleischprogramm unter besonderer Berücksichtigung des Tropfsaftverlustes

Ziel der Arbeit war es, anhand einer Stichprobe von 534 Schweinen aus 3 Kreuzungszuchtprogrammen verschiedene Fleischbeschaffenheitsindikatoren auf ihre Eignung als Sortierkriterium am Schlachthof zu überprüfen. Im Fokus eines fiktiven Qualitätsfleischprogrammes stand die Verringerung des Tropfsaftverlustes. Dabei wurde neben dem Herkunftseffekt insbesondere der MHS-Status als Einflussgröße untersucht. Schwerpunkt der Arbeit war es, die Effektivität von Leitfähigkeitsmessungen zur Sortierung von Schlachtkörpern mit möglichst reduziertem Tropfsaft einzuschätzen.

Im Ergebnis zeigte sich, daß der MHS-Status den größten Einfluß auf die Höhe der Tropfsaftbildung ausübte NN-Tiere wiesen ca. 2 Prozentpunkte geringere Tropfsaftverluste auf im Vergleich zu NP-Tieren. Im Vergleich der Herkünfte schnitt jene mit 25\% Duroc-Genanteil am vorteilhaftesten ab. Die Leitfähigkeit nach 24 Stunden erwies sich als das sicherste Kriterium zur Vorhersage des Tropfsaftverlustes, so dass die Verwendung von reinerbig streßstabilen Endprodukten (mit Duroc-Genanteil) in Kombination mit Leitfähigkeitsmessungen empfohlen werden kann, wenn die Reduktion von Tropfsaftverlusten im Rahmen eines Qualitätsfleischprogrammes im Vordergrund steht.

Schlüsselwörter: Schwein, Kotelett, Leitfähigkeit, Tropfsaftverlust, Duroc, MHS

\section{Introduction}

This research focuses on strategies to reduce drip loss of pork. Besides meat colour and marbling degree, drip loss largely contributes to the visual appearance of pork that 
is affecting the attractiveness of pork to consumers (BREWER and MCKEITH, 1999; NGAPO et al., 2007). Due to the increasing share of pre-packed meat for self-service the visual appearance at the point of sale is becoming even more important. Polarisation between discount and premium segments is being observed. Thus, in order to satisfy the premium consumer's need for constant and guaranteed quality it is necessary to produce and select carcasses with meat quality beyond the standard. Besides consumer aspects, the extend of drip loss affects the economic success of slaughter and packing plants. For example, in a big slaughter company handling 15.000 pigs per day, a $0.5 \%$ reduction of drip loss during the chill process will save more than $10.000 €$ per day assuming a price of $1.50 € / \mathrm{kg}$ and a mean slaughter weight of $95 \mathrm{~kg}$.

The mutation in the ryanodine receptor affecting the stress susceptibility (also known as malignant hyperthermia syndrome, MHS) has first been published by FUJII et al. (1991). Because this major gene has been shown to evoke unfavourable meat quality, breeding companies made efforts to eliminate the $\mathrm{P}$ allele entirely or at least from maternal lines (ROSENVOLD and ANDERSEN, 2003). However, most recently in Germany an increase in the P-allele proportion has been observed.

In Germany, monitoring of pork meat quality has been conducted in the past with last results from 2002 ("Warentest"). Usually these data are collected at animal testing stations that often provide optimal conditions in terms of animal handling etc. These lab-like quality tests may slightly positively bias the results compared to commercial slaughter facilities since the environment there is usually rougher in terms of handling stress, i.e. very careful handling of the pigs may diminish differences between MHSgenotypes that would appear under commercial circumstances.

We therefore intended to assess the meat quality characteristics of pig carcasses of three crossbreed types that were raised and slaughtered under commercial conditions. We further simulated post slaughter discrimination of superior carcasses where we focussed on reduction of drip loss. One major objective was also to quantify the effect of the MHS-genotype.

\section{Materials and methods}

This research included in total 534 pigs of three crossbreeds ( $G, H$, and S). Crossbreeds $\mathrm{G}$ and $\mathrm{H}$ were German Large White (LW) x German Landrace (LR) sows sired with Pietrain (PI) boars, i.e. PI x (LW x LR). Crossbreed S contained $25 \%$ Duroc (DU), i.e. PI x (DU x LR). The pigs were raised at several commercial farms (for each breed type the pigs were provided by at least two farms), fed with standard pig diet, and they were slaughtered in a commercial abattoir using electric stunning. With regard to known effects of saison (e.g. temperature stress during transport and lairage) sampling was nearly evenly distributed over one year (6 times). Thus, we realised a nearly fully balanced design: 6 dates $\times 3$ breeds $\times 2$ sexes (female and castrated male).

At slaughter, the carcasses for the research were randomly selected from the batches that were delivered by the companies each. Carcass data were provided by the slaughter company using a Fat-O-Meat'er grading probe (SFK Technology, D-59368 Werne, Germany). Early post mortal $\mathrm{pH}$-value of $M$. longissimus was measured at suspended carcasses in the region of the 2nd/3rd last rib 45 min post mortem (pH45) with the pH-Star instrument (Matthäus, D-04603 Klausa, Germany) before entering 
the chilling room. No prior shock cooling was applied. The next day the chilled carcasses were transported to the packing plant. There, electrical conductivity and $\mathrm{pH}$ were measured 24 hours post mortem at suspended carcasses (EC24, pH24) with LFstar and pH-star instruments, respectively (Matthäus, D-04603 Klausa, Germany). Loins were then detached from the carcass and cut across at the position of the $2 \mathrm{nd} / 3 \mathrm{rd}$ last rib. At the chop surface that was allowed to bloom for 10 minutes CIE-Lab colour values were recorded in triplicate on non overlapping sites with a CR-300 chromameter (Minolta, D-30855 Langenhagen, Germany) set at D65, $2^{\circ}$ observation angle. The loins were then transported 2 hours on ice to the university lab for further analyses. Drip loss of samples taken approximately 30 hours post mortem was measured according to the bag-method (Honikel, 1998) after 48 hours storage time at 4 ${ }^{\circ} \mathrm{C}$. Samples for chemical analysis were vacuum packed and frozen at $-20{ }^{\circ} \mathrm{C}$ until analysis. Prior to the analyses samples were thawed over night at $4{ }^{\circ} \mathrm{C}$. From an cutlet without adjacent fat layer the intramuscular fat (IMF) was extracted using a Soxtec apparatus (Foss, D-25462 Rellingen, Germany) with petrol ether as solvent with prior $\mathrm{HCl}$ pre-treatment according to German Food Legislation (LFBG, 2005). IMF values are given as percentage of fresh matter.

The c.1843C $>$ T SNP in the porcine RYR1 gene, responsible for the porcine MHS (FUJII et al., 1991), was genotyped using a Hin6I-PCR-RFLP. The polymorphic site was amplified in a $20 \mu \mathrm{l}$ PCR reaction containing $100 \mathrm{ng}$ genomic DNA extracted from the meat samples according to the standard phenol-chlorophorm procedure, 0.2 $\mu \mathrm{M}$ each forward (5'-TCCAGTTTGCCACAGGTCCTACCA) and reverse primer (5'ATTCACCGGAGTGGAGTCTCTGAG) respectively, $0.2 \mathrm{mM}$ dNTP and $0.5 \mathrm{U}$ Taqpolymerase (Genecraft, Lüdingshausen, Germany). The temperature profile included initial denaturation at $95^{\circ} \mathrm{C}$ for $3 \mathrm{~min}$, followed by 40 cycles of denaturation at $95{ }^{\circ} \mathrm{C}$ for $15 \mathrm{~s}$, annealing at $62{ }^{\circ} \mathrm{C}$ for $30 \mathrm{~s}$, extension at $72{ }^{\circ} \mathrm{C}$ for $60 \mathrm{~s}$, and one cycle of final extension at $72{ }^{\circ} \mathrm{C}$ for 5 min. Ten $\mu$ amplified DNA were digested using $10 \mathrm{U}$ Hin6I enzyme (Fermentas, St. Leon-Rot, Germany) overnight according to manufacturer recommendations, and the resulting RFLP was analyzed on 3\% ethidium bromide stained agarose gel.

Statistic analyses were performed with SAS software package V9.1 (SAS institute, Cary, USA). Analysis of variance was computed with the GLM procedure. Fixed effects included breed type, slaughter date, MHS genotype, sex and interaction effects. Effects that were not significant at the 0.05 level have been excluded from the analyses. Pairwise comparisons of least squares means were done with the option pdiff. Pearsons product moment correlations between parameters were calculated with SAS PROC CORR.

\section{Results and discussion}

Descriptive statistics of carcass composition and meat quality traits

Mean and variability of parameters under investigation are shown in Table 1 . Mean hot carcass weight was $95.1 \pm 5.9 \mathrm{~kg}$ whereas lean meat yield was approximately 57.6 $\%$ of hot carcass weight. Out of the parameter that indicate meat quality the variability of electrical conductivity (EC24) was higher compared to $\mathrm{pH} 45$. In fact, ultimate $\mathrm{pH}$ variability was lowest of all parameters. The coefficient of variation of drip loss was similar to that of EC24. 
Table 1

Descriptive statistics of carcass and meat quality characteristics, $n=534$ (Überblick über Schlachtkörper- und Fleischqualitätsparameter, $\mathrm{n}=534$ )

\begin{tabular}{lrrrrr}
\hline & Mean & Min & Max & S.D. & CV [\%] \\
\hline Carcass weight [kg] & 95.07 & 77.00 & 113.40 & 5.91 & 6.2 \\
Lean meat [\%] & 57.55 & 50.10 & 64.20 & 2.70 & 4.7 \\
pH45 & 6.41 & 5.70 & 7.00 & 0.22 & 3.4 \\
pH24 & 5.53 & 4.73 & 6.28 & 0.15 & 2.7 \\
EC24 [mS/cm] & 6.24 & 2.40 & 14.10 & 2.33 & 37.4 \\
L* & 47.34 & 38.76 & 59.51 & 2.76 & 5.8 \\
Drip loss 30-78h [\%] & 6.41 & 1.28 & 16.08 & 2.55 & 39.8 \\
\hline
\end{tabular}

In Table 2 the frequencies of MHS genotypes within crossbreed types is shown. For both breed type $\mathrm{G}$ and $\mathrm{H}$, the relative proportion of heterozygous animals is as low as $15 \%$. However, for breed type S the proportion of NP animals was more than $50 \%$. No homozygous MHS-positive animal was detected.

Table 2

Frequency of MHS-genotypes within breeds ( $n=534)$; NN = homozygous MHS negative; NP = heterozygous MHS genotype (Relative Häufigkeit der MHS-Genotypen innerhalb der Kreuzungsherkünfte bzw. über alle Schlachtkörper, $\mathrm{n}=$ 534; NN = homozygot MHS-negativ; NP = heterozygot)

\begin{tabular}{lcc}
\hline & \multicolumn{2}{c}{ MHS genotype } \\
\cline { 2 - 3 } Crossbreed type & $\mathrm{NN}$ & $\mathrm{NP}$ \\
\hline G: PI x (LW x LR); $\mathrm{n}=178$ & $84.8 \%$ & $15.2 \%$ \\
H: PI x (LW x LR); $\mathrm{n}=179$ & $84.4 \%$ & $15.6 \%$ \\
S: PI x (DU x LR); $n=177$ & $49.7 \%$ & $50.3 \%$ \\
total & $73.0 \%$ & $27.0 \%$ \\
\hline
\end{tabular}

\section{Analysis of variance}

For all traits crossbreed type, MHS genotype, date of slaughter, and crossbreed type*date interaction were significant (Table 3). Only for lean meat percentage, sex was included in the model for ANOVA since it was significant.

Table 3

Significance level of effects included in ANOVA (Signifikanzniveau der getesteten Effekte in der Varianzanalyse)

\begin{tabular}{lcccccc}
\hline trait & $\begin{array}{c}\text { Crossbreed } \\
(\mathrm{C})\end{array}$ & $\begin{array}{c}\text { Date } \\
(\mathrm{D})\end{array}$ & $\begin{array}{c}\text { MHS } \\
\text { type }\end{array}$ & $\begin{array}{c}\text { Sex } \\
(\mathrm{S})\end{array}$ & $(\mathrm{C} * \mathrm{D})$ & $(\mathrm{C} * \mathrm{~S})$ \\
\hline Carcass weight & $* * *$ & $* * *$ & $* * *$ & n.s. & $* * *$ & n.s. \\
Lean meat & $* * *$ & $* * *$ & $* * *$ & $* * *$ & $* * *$ & $* *$ \\
$\mathrm{pH} 45$ & 0.14 & $* * *$ & $* * *$ & n.s. & $* * *$ & n.s. \\
EC24 & $* * *$ & $* * *$ & $* * *$ & n.s. & $* * *$ & n.s. \\
Drip loss & $* * *$ & $* * *$ & $* * *$ & n.s. & $* * *$ & n.s. \\
\hline$* * * \mathrm{p}<.001, * * \mathrm{p}<.01 ;$ n.s. not significant & & & & & &
\end{tabular}

Least squares means with respect for crossbreed type, and MHS genotype are given in Table 4.

Castrated males yielded significantly less meat (57.04\%) than females (58.57\%). Carcasses of breed $G$ had significantly higher slaughter weight and nearly $1 \%$ more lean meat compared to the other breed types while NP-pigs outperformed NN-animals 
by more than $1 \%$ lean meat and higher carcass weight (Table 4). However, NN carcasses performed more favourable in terms of meat quality traits: NN had significantly less drip loss (5.81 \%) compared to NP (8.04\%). Accordingly, homozygous (NN) animals had higher initial $\mathrm{pH}$-value, and lower conductivity values (EC24) than heterozygous pigs. Date of slaughter did significantly affect the traits under investigation (data not shown). Since that effect is also confounded with the effect of farm, interpretation of these results is not unambiguous. The higher slaughter weight of breed $\mathrm{G}$ is suggested to be rather caused by the company delivering the pigs than to be a real breed effect.

Table 4

Carcass and meat quality traits with respect to crossbreed type and MHS genotype. Values are given as least squares means and standard error of the mean (Schlachtkörper- und Fleischbeschaffenheitskriterien in Abhängigkeit von der Kreuzungsherkunft bzw. vom MHS-Genotyp; jeweils LS-Means und Standardfehler)

\begin{tabular}{llllll}
\hline trait & $\mathrm{G}$ & $\mathrm{H}$ & $\mathrm{S}$ & $\mathrm{NN}$ & $\mathrm{NP}$ \\
\hline \multirow{2}{*}{ Carcass weight [kg] } & $96.10^{\mathrm{a}}$ & $94.15^{\mathrm{b}}$ & $95.94^{\mathrm{a}, \mathrm{c}}$ & $94.66^{\mathrm{a}}$ & $96.14^{\mathrm{b}}$ \\
& $(0.43)$ & $(0.44)$ & $(0.38)$ & $(0.27)$ & $(0.49)$ \\
Lean meat [\%] & $58.45^{\mathrm{a}}$ & $57.56^{\mathrm{b}}$ & $57.43^{\mathrm{b}}$ & $57.25^{\mathrm{a}}$ & $58.37^{\mathrm{b}}$ \\
& $(0.19)$ & $(0.19)$ & $(0.17)$ & $(0.18)$ & $(0.21)$ \\
pH45 & $6.39^{\mathrm{a}}$ & $6.37^{\mathrm{a}}$ & $6.41^{\mathrm{b}}$ & $6.45^{\mathrm{a}}$ & $6.34^{\mathrm{b}}$ \\
& $(0.02)$ & $(0.02)$ & $(0.01)$ & $(0.01)$ & $(0.02)$ \\
EC24 [mS/cm] & $7.39^{\mathrm{a}}$ & $7.02^{\mathrm{a}}$ & $6.54^{\mathrm{b}}$ & $5.41^{\mathrm{a}}$ & $8.56^{\mathrm{b}}$ \\
& $(0.16)$ & $(0.16)$ & $(0.14)$ & $(0.10)$ & $(0.18)$ \\
Drip loss [\%] & $7.28^{\mathrm{a}}$ & $7.58^{\mathrm{a}}$ & $5.92^{\mathrm{b}}$ & $5.81^{\mathrm{a}}$ & $8.04^{\mathrm{b}}$ \\
\hline
\end{tabular}

a,b,c: Means with different superscripts are significantly $(\mathrm{p}<0.05)$ different between breed types, and MHS genotypes, respectively.

Breed S pigs resulted in markedly lower drip loss compared to the other breeds. This is in accordance with earlier findings that pigs containing Duroc proportion show less drip loss (BLANCHARD et al., 1999; ARMERO et al., 1999; FISCHER et al., 2000). We did not observe significant drip loss differences between the breeds $\mathrm{G}$ and $\mathrm{H}$. Though the absolute differences are quite low, pH45 of breed S was significantly higher while EC24 was significantly lower compared to the other breed types, which is consistent with the drip loss results.

If not compensated for the effect of MHS genotype, breed S had the highest mean EC24 values (raw mean values: breed S: $6.53 \mathrm{mS} / \mathrm{cm}$; breed $\mathrm{H}: 5.95 \mathrm{mS} / \mathrm{cm}$; breed G: $6.26 \mathrm{mS} / \mathrm{cm}$ ) while having the lowest drip loss (S: $5.88 \%$; $6.92 \%$, G: $6.43 \%$ ). However, taking the MHS status into account, breed S has the lowest EC24 values (see Table 2). This is probably due to the large proportion of NP carcasses of breed G and $\mathrm{H}$. Thus, their means are corrected for MHS in a way that the ls-means are higher than the raw means.

The often compromising effect on meat quality of the ryanodine receptor mutation is well documented (ROSENVOLD and ANDERSEN, 2003). As for the effect of the MHS genotype on drip loss, most recently BORCHERS et al. (2007) also reported remarkable differences between NN (2.14 \%), NP (4.13\%), and PP (10.32 \%) purebred Pietrain in Germany. Comparing the absolute values the reader may please note, that often drip loss is collected for 24 hours compared to 48 hours collecting time in the present investigation. 


\section{PSE incidence}

$\mathrm{PH}$ value and electrical conductivity are most often used as indicators for meat quality and to discriminate pale, soft, exudative meat (= PSE) (WARRISS et al., 1998; JOSELL et al., 2003; ALTMANN et al., 2004). To do so, 2 less or more strict levels for each parameter were applied as can be seen in Table 5.

0.7 , and 2.8 percent of the carcasses, respectively are assumed to show PSE when pH45 $<5.8$ and $\mathrm{pH}<6.0$, respectively are used as threshold levels. However, applying EC24 values above 9 and $7 \mathrm{mS} / \mathrm{cm}$ as indicators, 15.2 and 36.0 percent of the samples, respectively are PSE-like. To evaluate the indicative power of EC24 and pH45, drip loss was comparatively used as threshold parameter: Saying $9 \%$ drip loss within 48 hours post mortem is related to PSE, $14.5 \%$ of the carcasses showed PSE conditions. Applying a more strict threshold of $7 \%$ drip, $35.3 \%$ of the carcasses fell in the PSE class. Concluding from these corresponding results of both EC24 and drip loss, about $30 \%$ of the carcasses ought to be classified as PSE-like. Within a recent monitoring in 6 commercial slaughter facilities in German that covered more than 20,000 carcasses (ALTMANN et al., 2005), the authors applied the more strict EC24 values greater than $7 \mathrm{mS} / \mathrm{cm}$. Dependent on the slaughter facility, they similarly concluded up to $27 \%$ of the carcasses to show PSE - in accordance with WARRISS et al. (1998) for carcasses in the EU based on pH values. Contrarily, JOSELL et al. (2003) also used the more strict threshold $\mathrm{pH} 45<6.0$ and found less than $6 \%$ of the carcasses showing PSE conditions whereas the genotypes did not include Pietrain.

Table 5

Comparison of PSE incidence in percent with relation to the indicating parameter, its threshold value and breed; $\mathrm{n}=534$ (Relative Häufigkeit des Auftretens von PSE in Abhängigkeit vom Indikationsparameter und der Kreuzungsherkunft bzw. des MHS-Genotyps)

\begin{tabular}{lccccccc}
\hline & \multicolumn{2}{c}{$\begin{array}{c}\text { Conductivity [mS/cm] } \\
\text { 24 h p.m. }\end{array}$} & \multicolumn{3}{c}{$\begin{array}{c}\text { Drip loss [\%] } \\
\text { 48-72 h p.m. }\end{array}$} & \multicolumn{2}{c}{$\begin{array}{c}\text { pH value } \\
\text { 45 min p.m. }\end{array}$} \\
\cline { 2 - 8 } & $>7$ & $>9$ & $>5$ & $>7$ & $>9$ & $<5.8$ & $<6.0$ \\
\hline G: PI x (LW x LR) & 31.5 & 11.2 & 70.2 & 36.0 & 16.8 & 0.6 & 1.1 \\
H: PI x (LW x LR) & 25.7 & 10.6 & 73.7 & 40.8 & 17.9 & 1.1 & 2.2 \\
S: PI x (DU x LR) & 40.1 & 23.2 & 57.6 & 31.0 & 10.7 & 0.6 & 5.1 \\
NN & 20.3 & 6.7 & 62.6 & 28.5 & 10.3 & 1.0 & 2.3 \\
NP & 65.3 & 37.5 & 79.9 & 56.3 & 28.5 & 0.0 & 4.2 \\
\hline total & 32.4 & 15.0 & 67.2 & 36.0 & 15.2 & 0.7 & 2.8 \\
\hline
\end{tabular}

However, the assessment of EC and subsequent evaluation of meat quality is dependent on instrument types and set up, e.g. frequency (LEE et al., 2000). In the present investigation the same instrument was used as by ALTMANN et al. (2005) suggesting the results to be comparable. Comparing the breeds, breed S pigs appeared inferior showing the highest percentage of PSE meat concluded from conductivity measurements (Table 5). Contrarily, referring to measured drip loss this breed is rather superior. Recently, Duroc-sired pigs were also reported being favourable in terms of PSE compared with Pietrain-sired pigs (RAUW et al., 2003). Also ARMERO et al. (1999), BLANCHARD et al. (1999) and FISCHER et al. (2000) noted lower drip loss for crossbreeds including Duroc proportions. Similar to the present results RAUW et al. (2003) found Duroc-sired pigs having the lowest conductivity values 24 hours post mortem. 
Comparing the MHS genotypes, only half as much homozygous stress resistant pigs (NN) exceed drip loss greater $7 \%$ compared to NP pigs. Correspondingly, $20 \%$ of NN carcasses ought to be classified as PSE concluding from the EC24 threshold of 7 $\mathrm{mS} / \mathrm{cm}$. However, nearly two out of three NP genotypes exceed that conductivity threshold value.

\section{Correlations}

Table 6 to Table 10 show correlations between carcass characteristics and meat quality traits with respect to MHS genotype and crossbreed type, respectively. There is hardly any relation between lean meat yield or carcass weight and drip loss. However, for all carcasses there is a significant negative relation between lean meat yield and intramuscular fat content. The closest relationship can be observed between EC24 and drip loss. Dependent on MHS genotype and crossbreed type, correlation coefficients range from .35 (breed S, NP) up to .72 (breed G, NP). Generally, the correlations confirm the ability of EC24 as indicator for drip loss as proposed above. For genotype $\mathrm{S}$ the relation between conductivity and drip loss is lower. We suggested a breed type dependency that is due to tissue matrix differences (MÖRLEIN et al., 2007).

Table 6

Correlations (and their significance) between carcass and meat quality for all carcasses; $\mathrm{n}=534$ (Korrelationen zwischen Schlachtkörper- und Fleischbeschaffenheitsmerkmalen für alle untersuchten Schlachtkörper)

\begin{tabular}{|c|c|c|c|c|c|}
\hline & Meat \% & Weight & EC24 & Drip loss & IMF \\
\hline Meat \% & & $\begin{array}{r}-0.118 \\
(0.0065)\end{array}$ & $\begin{array}{r}0.058 \\
(0.1795)\end{array}$ & $\begin{array}{r}0.056 \\
(0.1932)\end{array}$ & $\begin{array}{r}-0.248 \\
(<.0001)\end{array}$ \\
\hline Weight & & & $\begin{array}{r}0.236 \\
(<.0001)\end{array}$ & $\begin{array}{r}0.012 \\
(0.7907)\end{array}$ & $\begin{array}{r}0.024 \\
(0.5827)\end{array}$ \\
\hline EC24 & & & & $\begin{array}{r}0.543 \\
(<.0001)\end{array}$ & $\begin{array}{r}-0.049 \\
(0.2537)\end{array}$ \\
\hline Drip loss & & & & & $\begin{array}{r}-0.057 \\
(0.1913)\end{array}$ \\
\hline
\end{tabular}

Table 7

Correlations (and their significance) between carcass and meat quality characteristics for all carcasses with respect to MHS-genotype: Values above diagonal are given for MHS-genotype NN ( $\mathrm{n}=390)$, values below diagonal are given for MHS-genotype NP $(n=144)$ (Korrelationen zwischen Schlachtkörper- und Fleischbeschaffenheitsmerkmalen für alle untersuchten Schlachtkörper in Abhängigkeit vom MHS-Genotyp; Genotyp NN ( $\mathrm{n}=390)$ oberhalb der Diagonale; Genotyp NP ( $=114)$ unterhalb)

\begin{tabular}{lrrrrr}
\hline & Meat \% & Weight & EC24 & Drip loss & IMF \\
\hline Meat \% & & -0.150 & -0.013 & 0.005 & -0.253 \\
& & $(0.0029)$ & $(0.8044)$ & $(0.9232)$ & $(<.0001)$ \\
Weight & -0.123 & & 0.242 & 0.024 & 0.018 \\
& $(0.1425)$ & & $(<.0001)$ & $(0.6345)$ & $(0.7242)$ \\
EC24 & -0.092 & 0.125 & & 0.533 & -0.030 \\
& $(0.2746)$ & $(0.1360)$ & & $(<.0001)$ & $(0.5505)$ \\
Drip loss & 0.005 & -0.137 & 0.390 & & -0.117 \\
& $(0.9485)$ & $(0.1016)$ & $(<.0001)$ & & $(0.0215)$ \\
IMF & -0.303 & 0.013 & -0.237 & 0.02974 & $(0.7235)$ \\
\end{tabular}


Table 8

Correlations (and their significance) between carcass and meat quality characteristics for crossbreed G with respect to MHS-genotype: Values above diagonal are given for MHS-genotype NN ( $\mathrm{n}=151$ ), values below diagonal are given for MHS-genotype NP $(n=27)$ (Korrelationen zwischen Schlachtkörper- und Fleischbeschaffenheitsmerkmalen für Herkunft G in Abhängigkeit vom MHS-Genotyp; Genotyp NN (n = 151) oberhalb der Diagonale; Genotyp NP ( $\mathrm{n}=27)$ unterhalb)

\begin{tabular}{lrrrrr}
\hline & Meat \% & Weight & EC24 & Drip loss & IMF \\
\hline Meat \% & & -0.142 & 0.022 & 0.020 & -0.238 \\
& & $(0.0830)$ & $(0.7900)$ & $(0.8103)$ & $(0.0033)$ \\
Weight & 0.342 & & 0.215 & -0.100 & 0.034 \\
& $(0.0804)$ & & $(0.0081)$ & $(0.2232)$ & $(0.6766)$ \\
EC24 & 0.146 & -0.130 & & 0.527 & 0.013 \\
& $(0.4662)$ & $(0.5192)$ & & $(<.0001)$ & $(0.8753)$ \\
Drip loss & 0.244 & -0.213 & 0.720 & & -0.097 \\
& $(0.2201)$ & $(0.2853)$ & $(<.0001)$ & & $(0.2375)$ \\
IMF & -0.042 & 0.073 & -0.591 & -0.424 & $(0.0275)$ \\
\end{tabular}

Table 9

Correlations (and their significance) between carcass and meat quality characteristics for crossbreed $\mathbf{H}$ with respect to MHS-genotype: Values above diagonal are given for MHS-genotype NN ( $n=151$ ), values below diagonal are given for MHS-genotype NP $(n=28)$ (Korrelationen zwischen Schlachtkörper- und Fleischbeschaffenheitsmerkmalen für Herkunft H in Abhängigkeit vom MHS-Genotyp; Genotyp NN (n = 390) oberhalb der Diagonale; Genotyp NP ( $\mathrm{n}=114)$ unterhalb)

\begin{tabular}{lrrrrr}
\hline & Meat \% & Weight & EC24 & Drip loss & IMF \\
\hline Meat \% & & -0.285 & -0.157 & 0.019 & -0.210 \\
& & $(0.0004)$ & $(0.0540)$ & $(0.8167)$ & $(0.0098)$ \\
Weight & -0.098 & & 0.215 & 0.11 & 0.096 \\
& $(0.6189)$ & & $(0.0080)$ & $(0.1752)$ & $(0.2414)$ \\
EC24 & 0.040 & -0.099 & & 0.526 & 0.092 \\
& $(0.8415)$ & $(0.6174)$ & & $(<.0001)$ & $(0.2609)$ \\
Drip loss & 0.205 & 0.164 & 0.357 & & -0.017 \\
& $(0.2955)$ & $(0.4049)$ & $(0.0624)$ & & $(0.8350)$ \\
IMF & 0.010 & 0.162 & -0.189 & 0.157 & $(0.4236)$ \\
\end{tabular}

As for differences between MHS genotypes, EC24 seems to be closer related to drip loss within NN carcasses $(r=.54)$ compared to NP carcasses $(r=.39)$. Generally, the results support earlier findings that electrical conductivity is a good predictor of drip loss when measured 24 hours post mortem (LEE et al., 2000). 
Table 10

Correlations (and their significance) between carcass and meat quality characteristics for crossbreed $\mathbf{S}$ with respect to MHS-genotype: Values above diagonal are given for MHS-genotype NN (n = 88), values below diagonal are given for MHS-genotype NP $(n=89)$ (Korrelationen zwischen Schlachtkörper- und Fleischbeschaffenheitsmerkmalen für Herkunft S in Abhängigkeit vom MHS-Genotyp; Genotyp NN (n = 88) oberhalb der Diagonale; Genotyp NP ( $\mathrm{n}=89)$ unterhalb)

\begin{tabular}{lrrrrr}
\hline & Meat \% & Weight & EC24 & Drip loss & IMF \\
\hline Meat \% & & -0.099 & 0.110 & -0.083 & -0.294 \\
& & $(0.3609)$ & $(0.3090)$ & $(0.4449)$ & $(0.0055)$ \\
Weight & -0.207 & & 0.353 & 0.195 & -0.066 \\
& $(0.0521)$ & & $(0.0007)$ & $(0.0700)$ & $(0.5389)$ \\
EC24 & -0.159 & 0.261 & & 0.417 & -0.001 \\
& $(0.1355)$ & $(0.0135)$ & & $(<.0001)$ & $(0.9911)$ \\
Drip loss & -0.239 & -0.134 & 0.349 & & 0.019 \\
& $(0.0244)$ & $(0.2122)$ & $(0.0008)$ & & $(0.8644)$ \\
IMF & -0.455 & -0.058 & -0.217 & -0.022 & $(0.8383)$ \\
\end{tabular}

Quality discrimination by means of EC24

Concluding from the indicative abilities of EC24 to predict drip loss, we simulated a quality program. The aim was to discriminate carcasses with inferior water holding capacity based on the suggested threshold of $7 \mathrm{mS} / \mathrm{cm}$. Carcasses that exceed that value will be excluded from the quality program to ensure a more homogenous batch in terms of drip loss. In Figure 1 the absolute proportions of carcasses that meet that requirement are shown. Of all carcasses, $32 \%$ exceed the threshold.

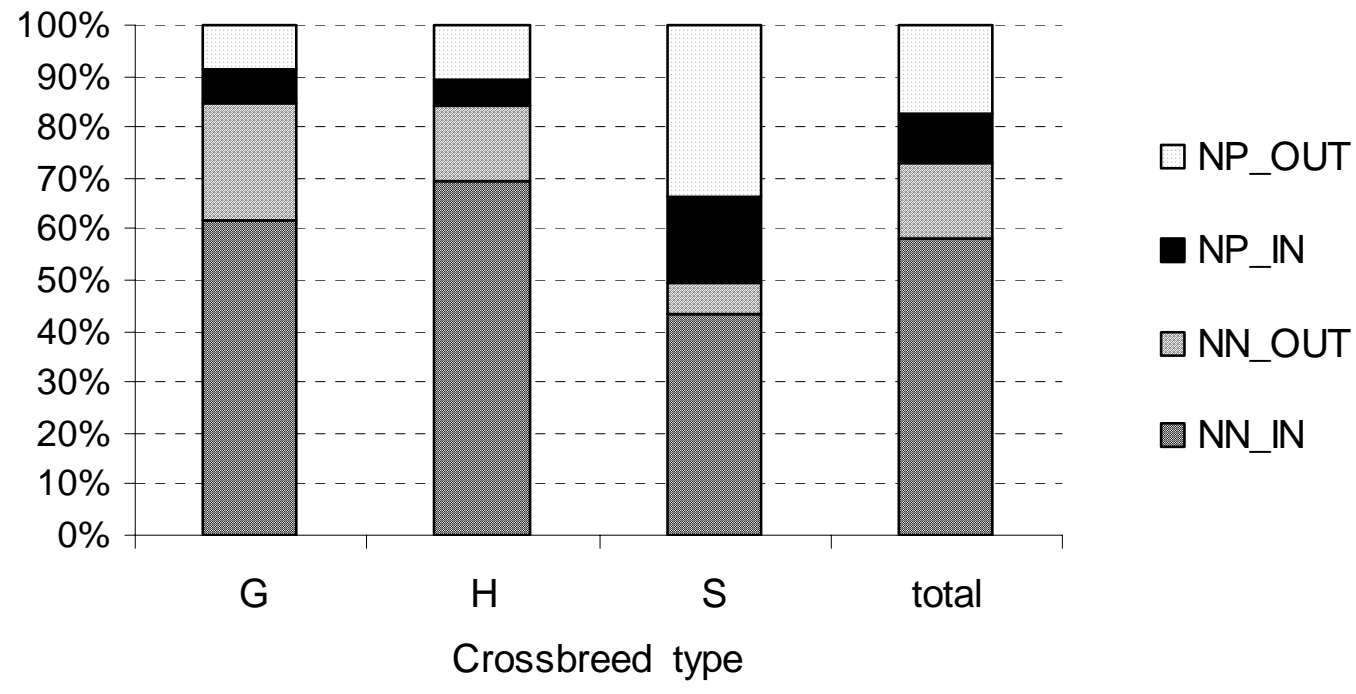

Fig. 1: Absolute proportion of carcasses within crossbreed type and MHS genotype IN/OUT the quality program based on EC24 (IN: EC24 <= 7 mS/cm; OUT: EC24 > 7 mS/cm). (Absolute Häufigkeit der Zugehörigkeit zum Qualitätsprogramm auf Basis von Leitfähigkeitsmessungen in Abhängigkeit von der Kreuzungsherkunft bzw. über alle untersuchten Schlachtkörper)

Looking at the relative proportions with respect to MHS genotype and crossbreed types, NN carcasses less frequently exceed the EC threshold (Figure 2). While around 
$80 \%$ of NN carcasses meet the program criteria, only $35 \%$ of NP carcasses yield EC24 values below $7 \mathrm{mS} / \mathrm{cm}$.
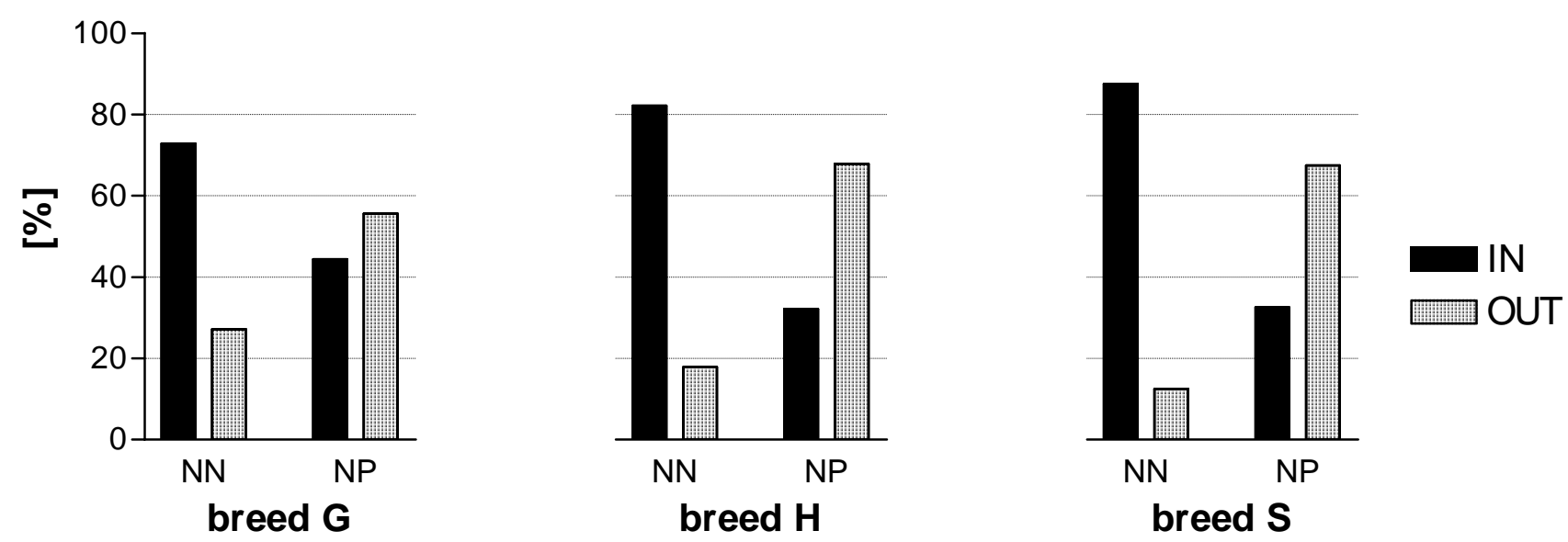

Fig. 2: Relative proportion of carcasses within crossbreed type and MHS genotype IN/OUT the quality program based on EC24 (IN: EC24 <= 7 mS/cm; OUT: EC24 > 7 mS/cm) (Relative Häufigkeit der Zugehörigkeit zum Qualitätsprogramm auf Basis von Leitfähigkeitsmessungen in Abhängigkeit von der Kreuzungsherkunft bzw. dem MHS-Genotyp)
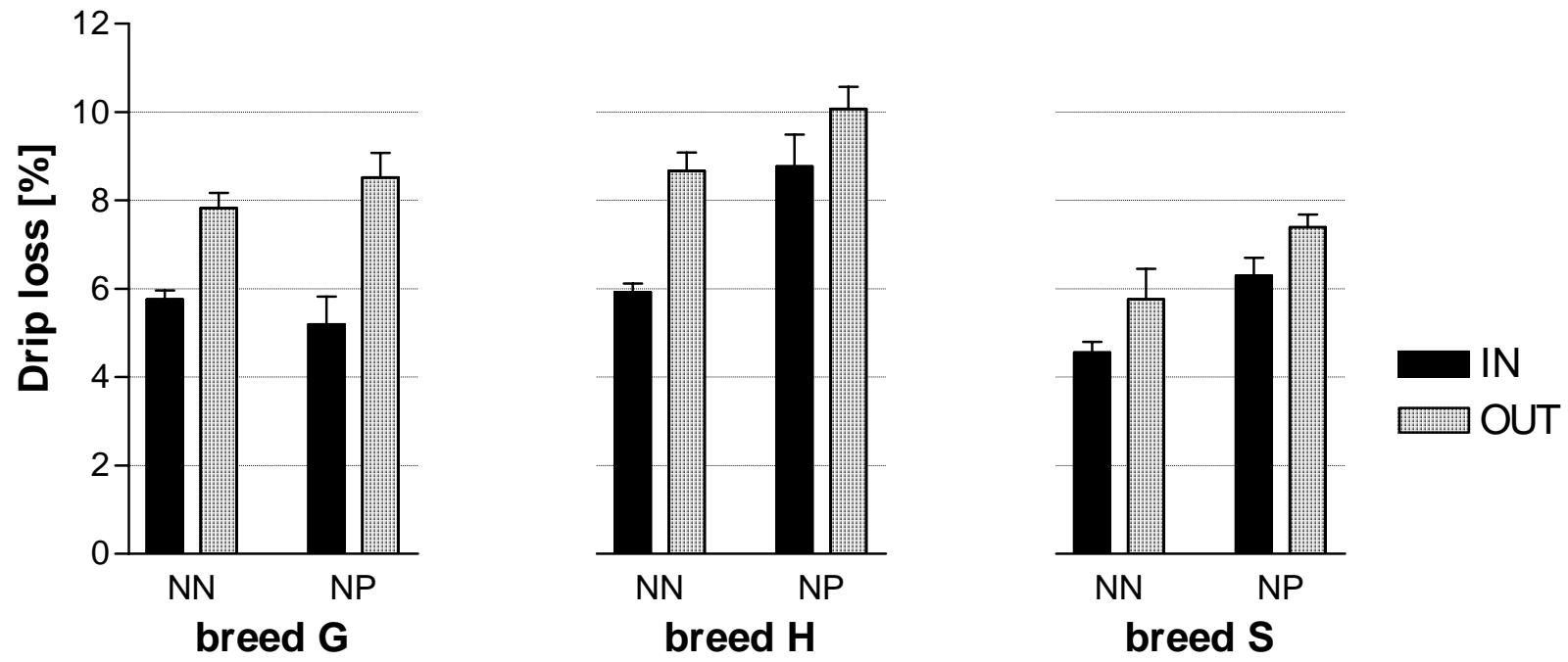

Fig. 3: Drip loss of carcasses with respect to crossbreed type, MHS genotype and quality class based on EC24 (IN: EC24 <= $7 \mathrm{mS} / \mathrm{cm}$; OUT: EC24 $>7 \mathrm{mS} / \mathrm{cm}$ ). LS-means and s.e. are given from the ANOVA (model drip loss $=$ crossbreed type + mhs genotype + quality class + crossbreed type*mhs*quality class) (Tropfsaftverlust in Abhängigkeit von der Kreuzungsherkunft, dem MHS-Genotyp und der Zugehörigkeit zum Qualitätsprogramm auf Basis von Leitfähigkeitsmessungen)

Figure 3 shows the corresponding mean drip loss values of carcasses within/out of the program. Carcasses within the program yield significantly less drip loss (LS-means: IN $=6.08$ (s.e. $=0.18$ ); OUT $=8.04$ (s.e. $=0.20$ ); $\mathrm{p}<.05$ ). For breed $\mathrm{G}$ and $\mathrm{H}$ the reduction of drip loss seems more effective compared to breed $\mathrm{S}$. We suggest this is because of the slightly less strong correlation of EC24 and drip loss as described above. Anyway the level of drip loss is lowest for breed S carcasses within the simulated program. Interestingly, the application of EC threshold discriminates even NP carcasses of breed type $G$ with relatively low drip loss. With no exception, drip loss of NP carcasses that have been sorted out, is highest. Besides the remarkable 

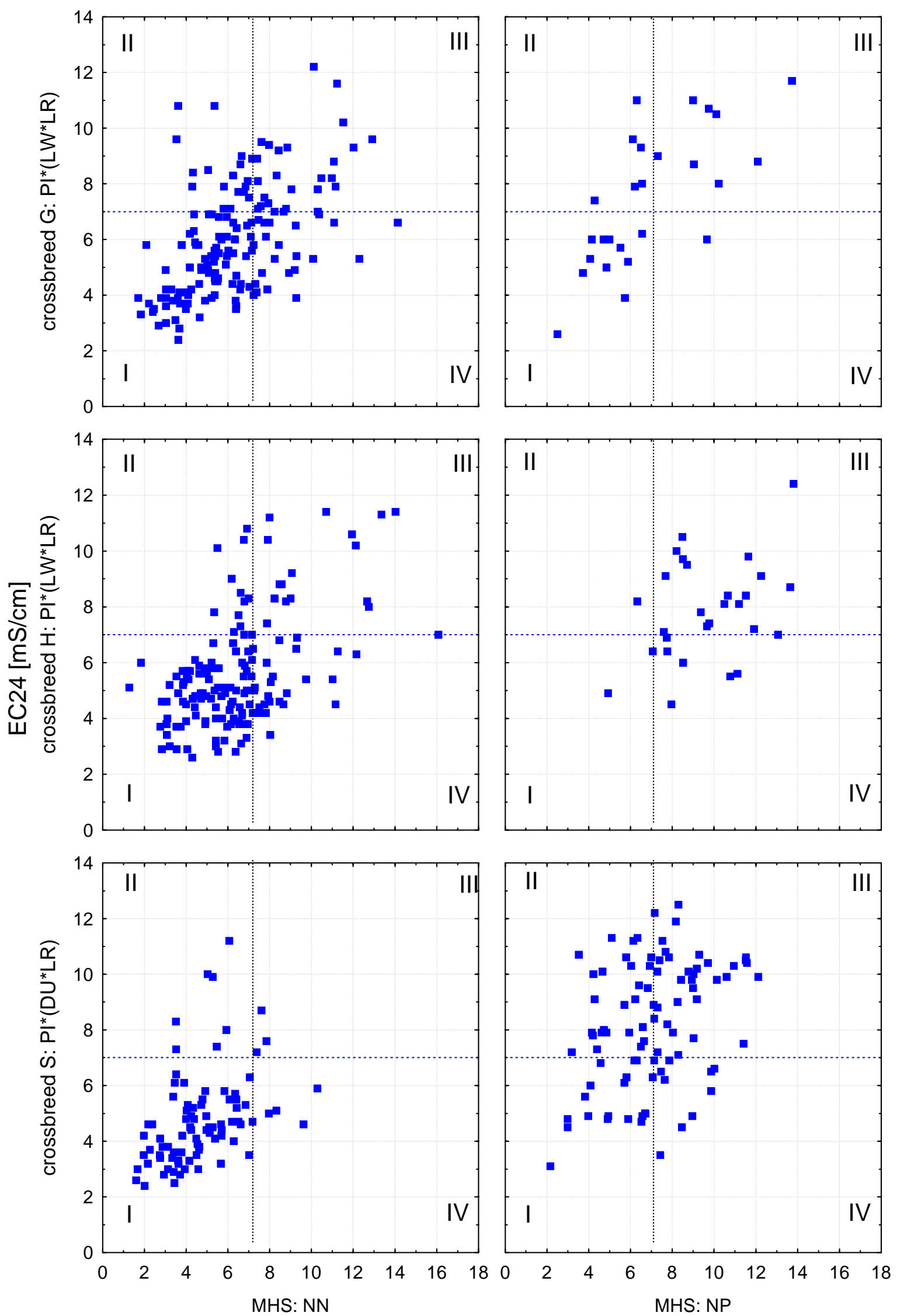

Drip loss [\%]

Fig. 4: Efficacy to discriminate superior carcasses with respect to drip loss according to their EC24 values. (Effektivität der Sortierung zum Zweck der Tropfsaftminimierung mittels Leitfähigkeitsmessungen) 
reduction of drip loss of those carcasses within the simulated program, a quite high variability remains (data not shown). THOLEN et al. (2005) also observed a high variability of drip loss within breed types. Estimated heritability $~ .25$ indicates that drip loss may further be reduced by means of genetic selection. Some breeding companies have been implementing drip loss in models for estimation of breeding values.

Apart from the correlation argument, EC was also chosen because it is rather easy to obtain at slaughter. Conductivity measurements are faster and less dangerous in terms of food safety compared to $\mathrm{pH}$ measurements (broken glass electrodes). The instruments are easier to maintain and to calibrate compared to $\mathrm{pH}$-meters.

Figure 4 shows the efficacy of EC24 to correctly discriminate carcasses with lower drip loss. Ideally all carcasses would be either in the $1^{\text {st }}$ or the $3^{\text {rd }}$ quadrant. As long as they are within the $1^{\text {st }}$ quadrant, they are correctly within the quality program due to low EC24 ( $<=7 \mathrm{mS} / \mathrm{cm}$ ) and low drip loss (below $7 \%$ ). Correspondingly, carcasses in the $3^{\text {rd }}$ quadrant are correctively sorted out due to high EC24 and high drip loss. Both carcasses in the $4^{\text {th }}$ quadrant and in the $2^{\text {nd }}$ quadrant are discriminated falsely. They have either low EC24 values despite a high drip loss (IV) or high EC24 but low drip loss (II).

Between MHS genotypes, the share of NN carcasses within the $1^{\text {st }}$ quadrant is higher compared to NP. Within NN, the proportion of correctly discriminated (I) carcasses is highest for breed $\mathrm{S}$ with $25 \%$ Duroc while the relative share of carcasses that are falsely sorted out ( $2^{\text {nd }}$ quadrant), and carcasses with high drip but low EC24 (4 $4^{\text {th }}$ quadrant), is lowest (Table 11). This is more favourable for applying EC to sort at slaughter. In Table 12 classification results for NP carcasses are given.

Table 11

Results of discrimination of NN carcasses according to EC24 and drip loss in percent (Übereinstimmung zwischen der Sortierung nach Leitfähigkeit und tatsächlichem Tropfsaft; MHS-Genotyp NN)

\begin{tabular}{|c|c|c|c|c|c|}
\hline \multirow[b]{2}{*}{ crossbreed } & & \multicolumn{4}{|c|}{ class } \\
\hline & & I & II & III & IV \\
\hline G: PI x (LW x LR) & & 53.64 & 10.60 & 16.56 & 19.21 \\
\hline H: PI x (LW x LR) & & 62.25 & 6.62 & 11.26 & 19.87 \\
\hline S: PI x (DU x LR) & & 79.55 & 9.09 & 3.41 & 7.95 \\
\hline & total & 62.82 & 8.72 & 11.54 & 16.92 \\
\hline
\end{tabular}

I: EC24<= $7 \mathrm{mS} / \mathrm{cm}$, drip loss <= $7 \%$; II: EC24 $>7 \mathrm{mS} / \mathrm{cm}$, drip loss $<=7 \%$

III: EC24 > $7 \mathrm{mS} / \mathrm{cm}$, drip loss > 7 \% IV: EC24 <= $7 \mathrm{mS} / \mathrm{cm}$, drip loss $>7 \%$

Table 12

Results of discrimination of NP carcasses according to EC24 and drip loss in percent (Übereinstimmung zwischen der Sortierung nach Leitfähigkeit und tatsächlichem Tropfsaft; MHS-Genotyp NP)

\begin{tabular}{|c|c|c|c|c|}
\hline \multirow[b]{2}{*}{ crossbreed } & \multicolumn{4}{|c|}{ class } \\
\hline & I & II & III & IV \\
\hline G: PI x (LW x LR) & 40.74 & 22.22 & 33.33 & 3.70 \\
\hline H: PI x (LW x LR) & 3.57 & 3.57 & 64.29 & 28.57 \\
\hline S: PI x (DU x LR) & 20.22 & 29.21 & 38.20 & 12.36 \\
\hline & 20.83 & 22.92 & 42.36 & 13.89 \\
\hline
\end{tabular}


In this study we characterized currently marketed pigs of three crossbreed types in terms of their carcass and meat quality while focussing on drip loss. Most of the parameters were affected by MHS genotype, crossbreed type, and date of slaughter. NN carcasses yielded 2 \% less drip loss compared to NP carcasses. Comparing the crossbreds, breed S pigs appeared most favourable because of lowest drip. Most probably that is due to the $25 \%$ Duroc proportion of that crossbred compared to $0 \%$ Duroc in the competitive crossbreds. Of all quality indicators obtained, conductivity was closest related to drip loss. Above all breeds, a remarkable decrease of drip can be achieved by application of EC24 measurements and corresponding sorting of the carcasses. The percentage of carcasses with EC24 > 7 is far higher among the NP pigs, regardless of crossbreed type. Contrarily, the share of carcasses with very low EC24 values is little in the NP population. Thus, at the production level drip loss can be most effectively reduced by using homozygous stress resistant pigs. Furthermore, by selection of certain crossbreed types the quality may further be improved. Within breeds, progress may be achieved as heritability estimates reported by VAN WIJK et al. (2005) ( $\mathrm{h}^{2}=.08$ for commercial crossbreds), BORCHERS et al. (2007) ( $\mathrm{h}^{2}=.14$ to .34 for purebred Pietrain) and HERMESCH et al. $(2000)\left(\mathrm{h}^{2}=.23\right.$ for Large White and Land race) suggest.

Besides the reduction of drip loss, also intramuscular fat content and sensory liking scores have been shown to increase with application of conductivity and lean meat yield thresholds to select carcasses with uniform and superior meat quality (MÖRLEIN et al., 2007). Also in this respect, breed S containing $25 \%$ Duroc appeared to be most favourable due to higher IMF values and sensory liking scores (data not shown). To establish a meat quality program, careful consideration of crossbreed type, MHS genotype and discrimination of superior carcasses at slaughter based on EC measurements is recommended.

\section{References}

LFBG:

Amtliche Sammlung von Untersuchungsverfahren nach § 64 LFGB: L 06.006 Bestimmung des Gesamtfettgehaltes in Fleisch und Fleischerzeugnissen. (2005)

ALTMANN, M.; KIRCHHEIM, U.; SCHÖBERLEIN, L.; WÄHNER, M.; WICKE, M.; FISCHER, K.:

PSE-Status bei marktkonformen Schweinen - Ergebnisse eines Monitorings in verschiedenen Schlachtbetrieben Deutschlands. Vortrag zur 39. Kulmbacher Woche 2004 an der BFEL Standort Kulmbach, 4./5.Mai 2004

ALTMANN, M.; KIRCHHEIM, U.; SCHÖBERLEIN, L.; WÄHNER, M.; WICKE, M.; FISCHER, K.: Incidence of PSE condition in market hogs - Monitoring results for various abattoirs in Germany. Fleischwirtschaft 85 (2005), 101-104

ARMERO, E.; FLORES, M.; TOLDRA, F.; BARBOSA, J. A.; OLIVET, J.; PLA, M.; BASELGA, M.: Effects of pig sire type and sex on carcass traits, meat quality and sensory quality of dry-cured ham. J. Sci. Food Agr. 79 (1999), 1147-1154

BLANCHARD, P. J.; WARKUP, C. C.; ELLIS, M.; WILLIS, M. B.; AVERY, P.: The influence of the proportion of Duroc genes on growth, carcass and pork eating quality characteristics. Anim. Sci. 68 (1999), 495-501

BORCHERS, N.; OTTO, G.; KALM, E.: Genetic relationship of drip loss to further meat quality traits in purebred Pietrains. Arch. Tierz., Dummerstorf 50 (2007), 84-91

BREWER, M. S.; MCKEITH, F. K.:

Consumer-rated quality characteristics as related to purchase intent of fresh pork. J. Food Sci. 64 (1999), 171-174

FISCHER, K.; REICHEL, M.; LINDNER, J. P.; WICKE, M.; BRANSCHEID, W.:

Eating quality of pork in well-chosen crossbreds. Arch. Tierz., Dummerstorf 43 (2000), 477-485 
FUJII, J.; OTSU, K.; ZORZATO, F.; DE LEON, S.; KHANNA, V. K.; WEILER, J. E.; O'BRIEN, P. J.; MACLENNAN, D. H.:

Identification of a mutation in porcine ryanodine receptor associated with malignant hyperthermia. Science 253 (1991), 448-51

HERMESCH, S.; LUXFORD, B. G.; GRASER, H.-U.:

Genetic parameters for lean meat yield, meat quality, reproduction and feed efficiency traits for Australian pigs: 1. Description of traits and heritability estimates. Livestock Prod. Sci. 65 (2000), 239248

JOSELL, A.; VON SETH, G.; TORNBERG, E.:

Sensory quality and the incidence of PSE of pork in relation to crossbreed and RN phenotype. Meat Sci. 65 (2003), 651-660

LEE, S.; NORMAN, J. M.; GUNASEKARAN, S.; VAN LAACK, R. L. J. M.; KIM, B. C.; KAUFFMAN, R. G.:

Use of electrical conductivity to predict water-holding capacity in post-rigor pork. Meat Sci. 55 (2000), 385-389

MÖRLEIN, D.; LINK, G.; WERNER, C.; WICKE, M.:

Suitability of three commercially produced pig breeds in Germany for a meat quality program with emphasis on drip loss and eating quality. Meat Sci. (2007) doi:10.1016/j.meatsci.2007.04.030

NGAPO, T. M.; MARTIN, J. F.; DRANSFIELD, E.: International preferences for pork appearance: I. Consumer choices. Food Quality and Preference 18 (2007), 26-36

RAUW, W. M.; VARONA, L.; RAYA, L. G.; NOGUERA, J. L.:

Meat production using four terminal pig lines. J. Sci. Food Agr. 83 (2003), 1504-1510

ROSENVOLD, K.; ANDERSEN, H. J.:

Factors of significance for pork quality--a review. Meat Science, 64 (2003), 219-237

THOLEN, E.; JÜNGST, H.; SCHULZE-LANGENHORST, CH.; SCHELLANDER, K.:

Genetic foundation of meat quality traits of station tested slaughter pigs in North Rhine-Westphalia (Germany). A status report. Arch. Tierz., Dummerstorf 48 (2005) Spezial Issue, 123-130

VAN WIJK, H. J.; ARTS, D. J. G.; MATTHEWS, J. O.; WEBSTER, M.; DUCRO, B. J.; KNOL, E. F.: Genetic parameters for carcass composition and pork quality estimated in a commercial production chain. J. Anim. Sci. 83 (2005) , 324-333

WARRISS, P. D.; BROWN, S. N.; GADE, P. B.; SANTOS, C.; COSTA, L. N.; LAMBOOIJ, E.; GEERS, R.: An analysis of data relating to pig carcass quality and indices of stress collected in the European Union. Meat Sci. 49 (1998), 137-144

Received: 2007-09-19

Accepted: 2007-10-09

Corresponding Author

Dr. DANIEL MÖRLEIN

University of Göttingen, Albrecht-Thaer-Weg 3, 37075 GÖTTINGEN, GERMANY

E-Mail: daniel.moerlein@agr.uni-goettingen.de 